\title{
Climatic control on clay mineral formation: Evidence from weathering profiles developed on either side of the Western Ghats
}

\author{
R DEePthy and S BALAKRISHNAN* \\ Department of Earth Sciences, Pondicherry University, Pondicherry 605 014, India. \\ *e-mail: sbala_2002@yahoo.com
}

\begin{abstract}
Many physico-chemical variables like rock-type, climate, topography and exposure age affect weathering environments. In the present study, an attempt is made to understand how the nature of clay minerals formed due to weathering differs in tropical regions receiving high and low rainfall. Clay mineralogy of weathering profiles in west coast of India, which receives about $3 \mathrm{~m}$ rainfall through two monsoons and those from the inland rain-shadow zones $(<200 \mathrm{~cm}$ rainfall $)$ are studied using X-ray diffraction technique. In the west coast, 1:1 clays (kaolinite) and $\mathrm{Fe}-\mathrm{Al}$ oxides (gibbsite/goethite) are dominant clay minerals in the weathering profiles while 2:1 clay minerals are absent or found only in trace amounts. Weathering profiles in the rain shadow region have more complex clay mineralogy and are dominated by 2:1 clays and kaolinite. $\mathrm{Fe}-\mathrm{Al}$ oxides are either less or absent in clay fraction. The kaolinite-smectite interstratified mineral in Banasandra profiles are formed due to transformation of smectites to kaolinite, which is indicative of a humid paleoclimate. In tropical regions receiving high rainfall the clay mineral assemblage remains the same irrespective of the parent rock type. Rainfall and availability of water apart from temperature, are the most important factors that determine kinetics of chemical weathering. Mineral alteration reactions proceed through different pathways in water rich and water poor environments.
\end{abstract}

\section{Introduction}

Weathering is the most fundamental and important of geomorphic processes, which plays a major role in the creation and modification of landforms and most importantly in the formation of soils. Chemical weathering of silicate minerals consumes a significant amount of $\mathrm{CO}_{2}$ and thus plays an important role in the carbon cycle and modelling climate (Amiotte-Suchet and Probst 1993; Huh 2003). A better understanding of the effect of climate on present day weathering has been achieved by geochemical study of rivers from different parts of the world (Probst et al 1994; White and Blum 1995; Mortatti and Probst 2003; Millot et al 2003). It is essential to know the relationship between the climate and the residual minerals that were formed as a result of weathering, in order to evaluate changes in the past climate of a region.

The rate and type of weathering is controlled by several factors such as mineralogy, climate, temperature, pressure and microbial activity. Among various factors controlling the process of weathering, climate plays a major role. For the study of weathering processes, climate can be regarded as a combination of variation in temperature (a physical factor) and rainfall (a chemical factor) (Velde 1992, p. 118). These variables affect the relative development of various parts of a weathering profile. Chemical and mineralogical changes occur in rocks due to weathering. Water is very essential for chemical weathering to take place and hence, an increase in rainfall leads to greater weathering. The same types of primary minerals

Keywords. Weathering; clay minerals; climate; Western Ghats; XRD. 
give rise to different secondary minerals when the conditions of weathering differ. Thus similar rock types undergoing weathering in different climatic conditions could give rise to distinct weathering profiles.

Bourgeon (2001) has studied the weathering patterns in the Western Ghat (Sahyadri) region and proposed hydrolysis as the major process of weathering in this region. He has proposed that monosiallitisation was the dominant process in the western part and bisiallitisation was the dominant process in the eastern part of Western Ghats. 1:1 and 2:1 clays were considered to have formed by monosiallitisation and bisiallitisation, respectively.

In the present study an attempt is made to understand how the climatic factor, especially rainfall, influences the type of weathering - essentially through the study of clay mineralogy of the weathering profiles. Clays are the common end products of weathering. Most of the clay materials are formed in the processes of weathering, either subaerial or subaquatic. They form when the silicate minerals formed at high temperature are hydrated due to the high water-to-rock ratio at the rockatmosphere interface. Thus, thermodynamically unstable silicates undergo incongruent dissolution to form clays during weathering process. Clays respond to their chemical and thermal environment and their properties and species change accordingly (Velde 1992, p. 3). Hence, a study of clay mineralogy is useful in understanding the weathering environment. The distribution of various clay minerals in sediments can be used as a tool for provenance studies (Pandarinath et al 1999).

The gneissic and granulite terrains of south India offer ideal conditions to study this effect. The Western Ghats defines the physiographic edge of more than $1800 \mathrm{~m}$ high in the southern Indian Shield. A spectacular escarpment with more than $700 \mathrm{~m}$ drop on the western side and a more gently sloping eastern side are the characteristics of this mountain range. A narrow tract between the Arabian Sea and the Western Ghats is a tropical humid region where the annual rainfall is of the order of $3500 \mathrm{~mm}$ whereas larger parts of southern Peninsular India to the east of the Western Ghats receive rainfall of $<1000 \mathrm{~mm}$. Thus, the significance of variable amounts of rainfall on chemical weathering can be studied with all the other climatic conditions being similar on either side of the Western Ghats.

\section{Study area}

Mangalore located in the west coast, Chikmagalore and Banasandra, which are in the rain shadow region of the Western Ghats were selected as field

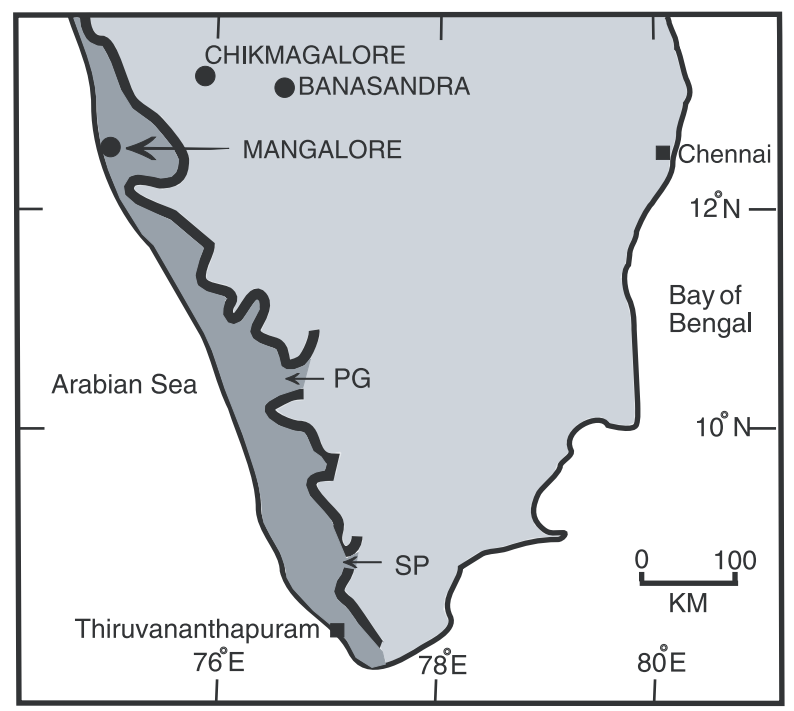

\section{- Study Areas \\ High Rainfall Area \\ Rain shadow area \\ PG Palghat Gap \\ SP Shencottah Pass}

Western edge of Western Ghats

Figure 1. Simplified map of southern India showing western edge of Western Ghats (Sahyadri). The west coast receives abundant rainfall of the order of $3500 \mathrm{~mm}$ per year whereas the hinter land to the east of Western Ghats receives much less annual rainfall of the order of less than $1000 \mathrm{~mm}$. Weathering profiles in and around Mangalore (in the west coast), Chikmagalore and Banasandra (areas in the rain shadow region) have been studied and these are indicated in the map.

areas based on the contrasting amount of rainfall that they receive (figure 1).

For characterizing the pattern of weathering, it is necessary to identify weathering profiles developed in situ. An ideal weathering profile shows different layers or horizons beginning from the topmost soil layer down to the unaltered parent rock. Saprock is partly weathered parent rock whose original petrographic structures are preserved. Above the zone of saprock, saprolite is formed where weathering is more intense and the original rock structure may be disrupted. The upper-most portion of the saprolite zone is part of the soil horizons. Top portion of the soil horizon consists of the organic rich layer.

\subsection{Weathering profiles around Mangalore}

Mangalore region experiences heavy annual rainfall varying from 1 to $3.5 \mathrm{~m}$ and a dry season of about five months per year (Dikshit 1979). Here weathering profiles are generally very deep over granitic gneisses and the unaltered parent rocks are not exposed to the surface in most places. These 
are highly lateritized areas and there are a number of quarries cutting out these laterites for making bricks.

More inland from the coast, some poorly developed weathering profiles were found over granulitic parent rocks. As suggested by Gunnell and Louchet (2000), probably due to a slower rate of weathering of massive granulites, deep profiles are not developed over them. A number of mafic enclaves were seen in profiles developed over granitic gneisses. The physical appearance of weathering patterns found on felsic and mafic rocks is well contrasted in the field by colour and the extent of weathering. In most of the profiles, all the minerals except quartz have been altered. In less weathered portions muscovites and biotites could be seen.

Samples from six different locations of Mangalore were studied. Weathering profiles M1 (Athyapadi village near Mangalore Airport), M2 (near Thodalagutta village) and M4 (Konchadi village) were developed over granitoid gneisses. Since the physical variation in weathering was less in these profiles, two samples each (bottom and top) were collected from these profiles. A number of mafic enclaves were seen at the location M4 and were sampled to study the difference in felsic and mafic weathering. M5 (near Kaikamba village) and M8 (Railway cutting between Feringipet and Adayar villages) represent profiles developed over weathered quarz bearing felsic granulites. Three samples were collected from location M10 (near Fisheries College) where several layers of laterites that were probably transported and deposited are found.

\subsection{Weathering profiles around Chikmagalore}

Chikmagalore is located in the Peninsular Gneissic Terrane and the parent rocks here are tonalite, granodiorite and granite. This falls in the rain shadow region and experiences a subtropical climate with the temperature varying from $20^{\circ} \mathrm{C}$ to $30^{\circ} \mathrm{C}$ and low average rainfall of less than $1000 \mathrm{~mm}$.

Deep profiles are scarcely seen in this area. Profiles found here are generally $\sim 2 \mathrm{~m}$ deep or less. Samples were collected from an in situ weathering profile formed over granodiorite-tonalite gneisses. At a depth of $1 \mathrm{~m}$ from the surface, a zone of saprock of $40 \mathrm{~cm}$ width was seen overlain by a saprolitic horizon of variable thickness $(25 \mathrm{~cm}$ at the sampling point). A 'stone line' of about $14 \mathrm{~cm}$ width consisting of silicretes and ferricretes was found developed above saprolites and on top of this the most weathered zone of the profile exists. Altered boulders of parent rock are found scattered within the bottom-most part of the weathering profile. The top $20 \mathrm{~cm}$, which was part of the topsoil, was not sampled.

\subsection{Weathering profiles around Banasandra}

Banasandra is located within the Archean Chitradurga supracrustal belt in the Dharwar Craton, Karnataka. The parent rocks here are metamorphosed basalts, ultramafic rocks and detrital sediments. The area is situated in the rain shadow region of Western Ghats and receives less than $1000 \mathrm{~mm}$ rainfall. Some good profiles were developed and exposed along the newly dug irrigation canals in the ultramafic terrain around Banasandra.

Samples were collected from a well-developed weathering profile formed over ultramafic rocks in a canal cutting (13/1) (figure 2a). The unaltered parent rock was not visible and the bottom-most part looked like saprolite. The sample collected from this part at a depth of $7 \mathrm{~m}$ was black in colour with yellow stains. Another sample was collected from a depth of about $4.5 \mathrm{~m}$ and this appeared to be more weathered. Two more samples one at $2.3 \mathrm{~m}$ and another at $1.5 \mathrm{~m}$ were collected from this profile.

Four samples were collected from a weathering profile $(14 / 2)$ developed over metabasalt exposed along a stream cutting $10 \mathrm{~km}$ north of Banasandra. The parent rock was highly foliated with intense zones of fracturing. Extent of weathering is much more in these zones compared to the top-most part of the weathering profile.

Seven samples were collected from weathering profile $(15 / 1)$ exposed in an abandoned pit occurring $10 \mathrm{~km}$ east of Nittur on the southern side of the Tumkur-Shimoga road (figure 2b). The parent rock was not exposed but from the pattern of weathering it was inferred to be granitic gneiss. Total width of the profile was $3.5 \mathrm{~m}$ and in the topmost part within the soil layer there was a thin stone line. The profile had a light yellow colour layer below the stone line and plant roots were seen up to this layer. Further below this layer, the profile turns to dark brown in colour and a quartzofeldspathic vein was seen within this zone. The bottom-most layer was having purple and yellow colour and quartz grains were prominently seen within this zone.

A deep canal section (16/2) of about $14 \mathrm{~m}$ depth was found on metasedimentary rocks (greywacke). The whole profile was divided into three benches and samples were collected from different zones in the profile. The fresh rock was not exposed at the bottom. The bottom-most portions of this profile have preserved the original rock structure. The rock was clearly layered and weathered feldspars and mafic minerals were visible in hand specimens. Here the rocks were deep yellow coloured which changes to pale-yellow upwards. Shiny white portions of feldspar altering to clay could be seen in 

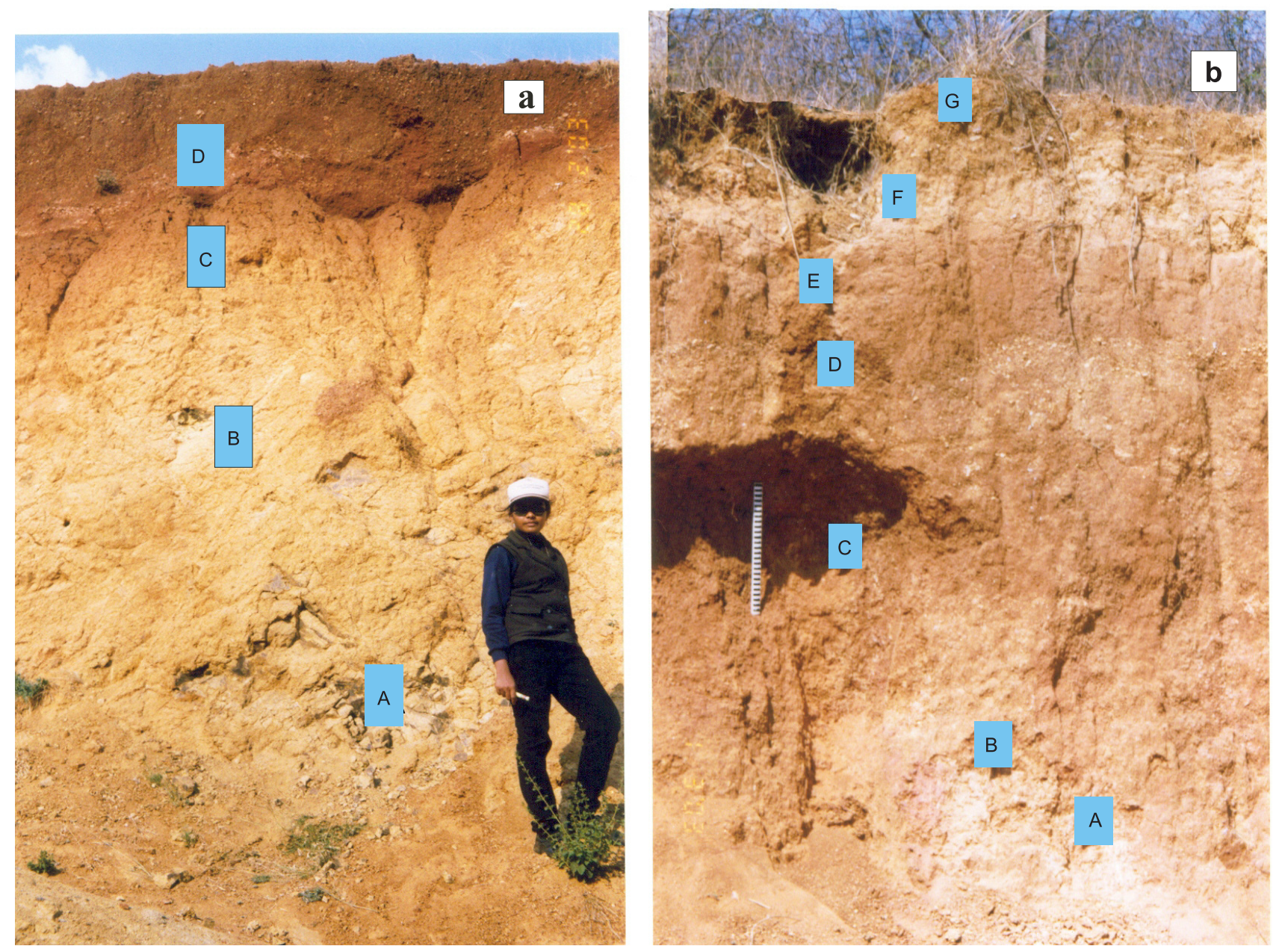

Figure 2. Photographs of weathering profiles in and around Banasandra. (a) Weathering profile (13/1) developed over ultramafic rocks. Sampling points are indicated in figure as A, B, C and D. The total depth of the profile is around $7 \mathrm{~m}$. The top portion consists of transported materials and hence not sampled. The original rock structure is visible in the bottom-most part of the profile. (b) Weathering profile (15/1) developed over granitic rocks. Labels A to G indicate sampling points. No original rock structure is preserved in this profile. Total depth of the profile is around $4 \mathrm{~m}$.

more weathered layers. In bench II, partly weathered micas could be seen. The profile did not show any gradual up-profile increase in weathering intensity, but the most weathered appearance was seen in the intermediate depth of the whole profile. The top portion consisted of some secondary laterites, which do not appear to have been derived from or part of this profile. Although the process of weathering had affected the rocks to more than $14 \mathrm{~m}$ depth, the amount of clay minerals present and therefore, the extent of chemical weathering seemed to be less compared to the Mangalore area.

\section{Materials and methods}

Samples were collected from well developed in situ weathering profiles found along road and canal cuttings and in quarries. In a profile, different zones were identified based on the degree of weathering, identified by various physical parameters such as colour, grain size, compactness, rock structure, texture, etc. and representative samples were collected from each zone. The top $5-15 \mathrm{~cm}$ was not sampled to avoid the surface contamination. In each zone, the outer most part is scraped off before sample collection to reduce the effect of any external leached material.

A total of 44 samples, fourteen from six profiles around Mangalore, twenty six samples from four profiles around Banasandra and four samples from a profile around Chickmagalore, were taken up for the present study.

\subsection{Clay mineral separations and analysis}

Clays are materials that are less than $2 \mu \mathrm{m}$ in equivalent spherical diameter and separated from the bulk samples using the settling technique (Hardy and Tucker 1988). Complete disaggregation 
of the particles was achieved by giving ultrasonic treatment to the sample kept in a beaker with distilled water for 30 minutes (Gipson 1963). If the sample contains significant amounts of organic matter, the X-ray diffraction peaks will be broad and the background will be increased. To remove the organic matter, diluted hydrogen peroxide solution was used. The samples were washed thoroughly with distilled water after this treatment. The samples were wet-sieved to remove the particles coarser than $65 \mu \mathrm{m}$ and deflocculated by the addition of sodium hexametaphosphate solution (10\%) (Calgon) when the sample was suspended in the settling column.

The clay-sized fraction was separated using Stokes' Law. From the standard table (after Galehouse 1971 as given in Hardy and Tucker 1988) the appropriate time of withdrawal of the sample was calculated as 3 hours and 36 minutes. After this much time the liquid-suspension in the top $5 \mathrm{~cm}$ of the column was siphoned out. This suspension was split into two fractions and one was saturated with $\mathrm{Ca}^{2+}$ and other with $\mathrm{K}^{+}$ions and from these oriented slides were prepared. Ca-saturated samples were analyzed in air-dried condition and also after ethylene glycol solvation. $\mathrm{K}$-saturated samples were scanned at room temperature after heating to $110^{\circ} \mathrm{C}, 300^{\circ} \mathrm{C}$ and $550^{\circ} \mathrm{C}$.

Clay mineral analyses were carried out using a PAnalytical XPert Pro ${ }^{\mathrm{TM}}$ X-Ray Diffractometer (XRD) equipped with a copper target, operating at $40 \mathrm{kV}$ and $25 \mathrm{~mA}$. XRD patterns of oriented clay slides were recorded using a step size of $0.02^{\circ} 2 \theta$ and a scan speed of $0.6^{\circ} 2 \theta / \mathrm{min}$ and scanned from $2^{\circ}$ to $30^{\circ} 2 \theta$. Clay minerals were identified following the methods of Brown and Brindley (1980). A semi-quantitative estimation of clay minerals was done from peak area using the formula

$$
\begin{aligned}
& \% \text { clay mineral } \\
& =100 \times\left[I_{\text {clay mineral }} / \Sigma I_{\text {all clay minerals }} \text { in the sample }\right]
\end{aligned}
$$

where $I=$ peak area of the clay minerals used. For all the samples where smectites were present, the Ca-saturated, glycolated patterns were used for semi-quantification. The peaks used for semi-quantification are: smectites $-17 \AA$, kaolinite-smectite and kaolinite $-7 \AA$, clay mica - $10 \AA$, gibbsite $4.8 \AA$, goethite $-4.18 \AA$. Result of this analysis is summarized in tables 1 and 2 .

\section{Results}

\subsection{Weathering profiles in the west coast}

Weathering profiles around Mangalore area are generally very deep and matured. The clay mineralogy of weathered granitic gneisses collected from a quarry in Athyapadi near Mangalore airport is dominated by kaolinite and gibbsite. In the XRD pattern, kaolinite is identified by the 001 reflection with a $d$ value of $7.2 \AA$, which disappears on heating to $550^{\circ} \mathrm{C}$ (figure 3a). This peak is sharp and almost symmetrical in less weathered sample (M1A) whereas it is broad, short and symmetrical in intensely weathered sample (M1B) (figure 3b). Gibbsite is identified by the sharp $4.8 \AA$ peak which becomes more intense on $\mathrm{K}$ saturation and almost disappears on heating to $300^{\circ} \mathrm{C}$ (figure 3a). Goethite is identified by a peak at about $4.16 \AA$. Trace amounts of clay mica is identified by a weak reflection at $10 \AA$ in M1A. Weathered granitic gneisses from Thodalagutta are characterized by slightly different clay mineralogy. The sample that appeared less weathered in field (M2A) contains gibbsite as the dominant clay mineral followed by kaolinite (figure $3 \mathrm{~b}$ ). The gibbsite peak is very sharp but the kaolinite peak is short and broad indicating poor crystallanity of this kaolinite. The sample that appeared to be more weathered in the hand specimen (M2B) contains kaolinite as the major clay mineral followed by gibbsite. A small amount of goethite also appears in this sample.

Samples collected from a profile (M4) developed over granitic gneisses show well crystalline kaolinite along with a small amount of gibbsite and goethite (figure 3b). A weathered profile over a mafic enclave found within the felsic granite also has kaolinite, gibbsite and goethite in the clay fraction.

Weathered granulites collected from different profiles (M5 and M8) show similar clay mineralogy with small amounts of clay mica, gibbsite and/or goethite $(<3 \%)$ along with a high abundance of kaolinite $(>90 \%)$ (table 1$)$. The $7.2 \AA$ peak of kaolinite shows a tailing in the low angle region indicating the possible presence of trace amounts of interstratification with a 2:1 mineral as observed in other regions also (Srivastava et al 1998; Omotoso and Mikula 2004). However, $14 \AA$ or $17 \AA$ reflections were absent in these samples, thus ruling out the presence of distinct smectite, vermiculite and chlorite (figure $3 \mathrm{c}$ ).

Two samples collected from laterites exposed near Fisheries College, Mangalore (M10 B and C) have almost well crystalline kaolinite in its clay fraction. A small amount of goethite also shows up in one of them. The shape of the kaolinite peak of sample M10 A shows evidence for interstratification of kaolinite with trace amounts of 2:1 clays (figure 3c). Thus it could be inferred that the laterites at this site could have been derived from two different sources, i.e., granitic gneisses and granulites. 


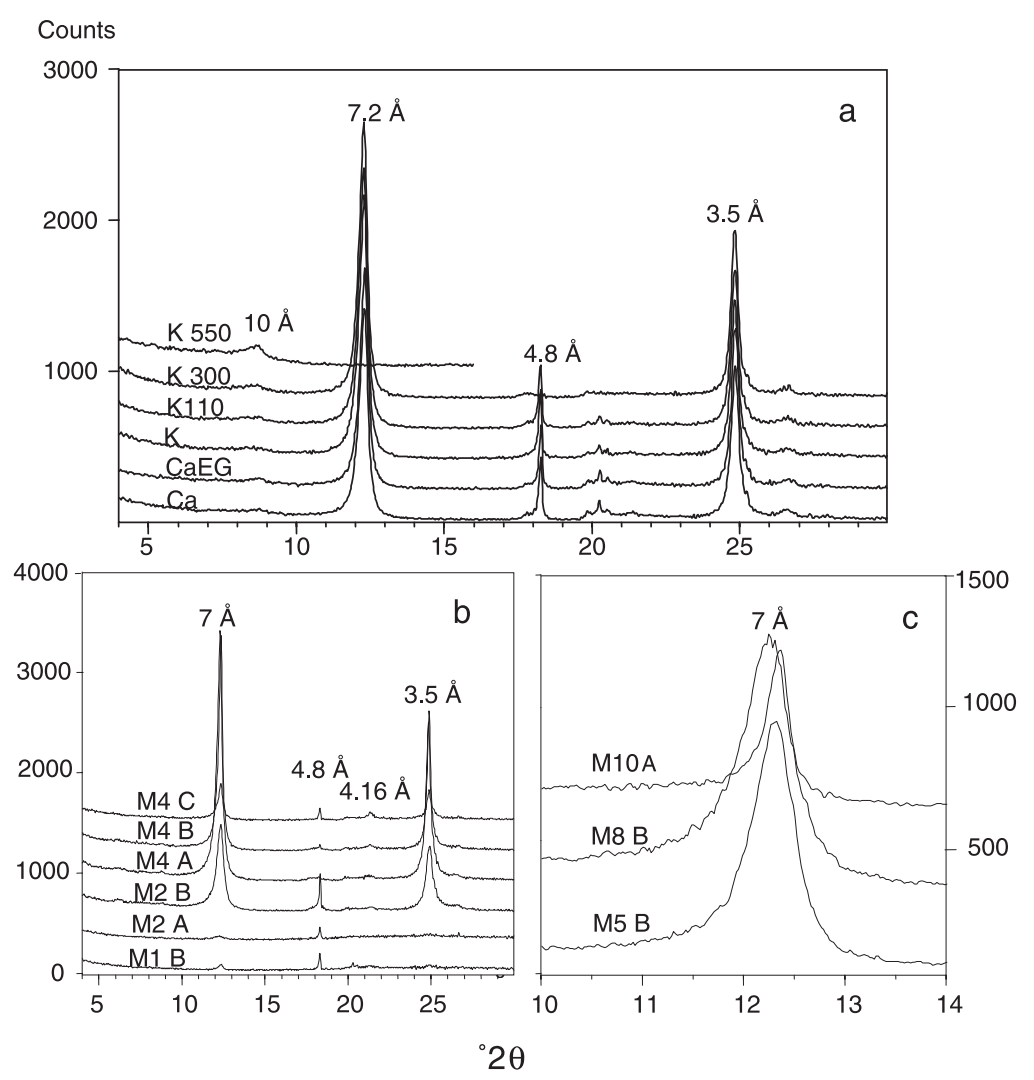

Figure 3. XRD patterns of clay fraction in samples from Mangalore, where intensity of reflected X-rays are plotted against $2 \theta$ values. Peaks are labeled with corresponding d-spacing in $\AA$ units. Sample numbers are marked over the XRD patterns. (a) XRD patterns of sample M1A after giving following treatments. $\mathrm{Ca}^{2+}$ saturation (Ca), glycolation $(\mathrm{CaEg}), \mathrm{K}^{+}$saturation (K), heating to $110^{\circ} \mathrm{C}(\mathrm{K} 110), 300^{\circ} \mathrm{C}(\mathrm{K} 300), 550^{\circ} \mathrm{C}(\mathrm{K} 550)$. The $7.2 \AA$ peak which is sharp and symmetrical represents kaolinite. Note the disappearance of this peak after heating $550^{\circ} \mathrm{C}$. The $4.8 \AA$ peak represents gibbsite and the $10 \AA$ peak represents clay mica. (b) XRD patterns of Ca-saturated samples from different weathering profiles around Mangalore. The $4.16 \AA$ peaks represent goethite. (c) Part of the XRD patterns for samples (Ca saturated) from three different weathering profiles around Mangalore shown in expanded scale between $10^{\circ}$ and $14^{\circ} 2 \theta$. Note the low angle asymmetry of the $7 \AA$ kaolinite peak in these samples.

Regardless of the parent rock type, the clay mineral assemblage found in weathering profiles around Mangalore are dominated by kaolinite with either one or both the oxy-hydroxide minerals (kaolinite \pm goethite \pm gibbsite). Thus, the weathering of rocks in the high rainfall areas around Mangalore gives rise to dominantly $\mathrm{Fe}-\mathrm{Al}$ oxides and 1:1 clays irrespective of the parent rock composition.

\subsection{Weathering profiles in the rain shadow region}

Samples from profiles developed over granitic parent rock in Chikmagalore have kaolinite as the major clay mineral, whereas, gibbsite is absent. Quartz peaks are prominently seen up to the top layer along with kaolinite.

In Banasandra area, the profiles on ultramafic rocks (13/1) have smectite as the major clay mineral with prominent $15 \AA$ peak in Ca-saturated sample that shift to $17 \AA$ after glycolation (figure 4a). As the $15 \AA$ peak collapses to $12 \AA$ on $\mathrm{K}$ saturation at room temperature and to $11 \AA$ at $110^{\circ} \mathrm{C}$ it is inferred that these are low-charge smectites and from the peak shape these appear to be fairly well crystalline. Strong 060 reflection at $1.5 \AA$ indicates that these are dioctahedral smectites although weak reflections of $1.54 \AA$ indicate the presence of small amounts of trioctahedral mineral (figure 4b inset). The $7.2 \AA$ peaks of kaolinite with a broad base show plateau in the low angle region, indicating that these kaolinites are interstratified with smectite. However, the shift of $7.2 \AA$ peak to $8 \AA$, regarded as characteristic of kaolinitesmectite interstratification (Schultz et al 1971), is not shown by these samples. On heating the sample to $550^{\circ} \mathrm{C}$, the $7.2 \AA$ peak disappears and the $10 \AA$ peak becomes more intense compared to $110^{\circ} \mathrm{C}$ and $300^{\circ} \mathrm{C}$ heated peaks and shows a low angle tail. Based on the above observations, it is inferred that the interstratified smectite is hydroxy interlayered smectite (HIS). The percentage of interstratification could not be estimated, as there was no shift 
Table 1. Clay mineralogy of weathering profiles developed around Mangalore located west of the Western Ghats.

\begin{tabular}{|c|c|c|c|c|c|}
\hline \multirow{2}{*}{$\begin{array}{l}\text { Parent } \\
\text { rock type }\end{array}$} & \multirow{2}{*}{$\begin{array}{c}\text { Sample } \\
\text { no }\end{array}$} & \multicolumn{4}{|c|}{$\begin{array}{l}\text { Clay mineral abundance } \\
\text { in percentage }\end{array}$} \\
\hline & & kao & $\mathrm{cm}$ & gibb & goe \\
\hline Granitic & M1 B & 37.9 & - & 51.5 & 10.6 \\
\hline Gneiss & M1 A & 88.1 & 1.5 & 10.4 & - \\
\hline Granitic & M2 B & 88.9 & 1.3 & 8 & 1.8 \\
\hline Gneiss & M2 A & 46.8 & $\operatorname{Tr}$ & 53.2 & - \\
\hline $\begin{array}{l}\text { Mafic } \\
\text { Enclave }\end{array}$ & $\mathrm{M} 4 \mathrm{C}$ & 76.8 & - & 9.9 & 13.3 \\
\hline Granitic & M4 B & 96.8 & - & 1.4 & 1.8 \\
\hline Gneiss & M4 A & 98.7 & - & 0.2 & 1.1 \\
\hline Granulite & M5 B & 94.6 & 1.1 & 1.5 & 2.9 \\
\hline Granulite & M8 B & 95.6 & 2.7 & - & 1.7 \\
\hline Secondary & M10 C & 96.8 & - & - & 3.2 \\
\hline laterites & M10 B & 84.2 & - & - & 15.8 \\
\hline & M10 A & 91.4 & - & - & 8.6 \\
\hline
\end{tabular}

kao = kaolinite $\mathbf{c m}=$ clay mica $;$ gibb = gibbsite $;$ goe $=$ goethite; $\operatorname{Tr}=$ trace amounts.

of $7.2 \AA$ peak on glycolation. Although $14 \AA$ peak is absent in these samples, a trace amount of vermiculite is identified by the appearance of $10 \AA$ peak on $\mathrm{K}$ saturation at room temperature, which is reinforced through heating.

The amount of smectite increases and the amount of kaolinite-smectite decreases as we go down the profile (figure $7 \mathrm{a}$ ). The presence of small amounts (less than 3\%) of goethite (Fe oxyhydroxides) was inferred in the upper part of the profile from the $4.18 \AA$ peak (table 2).

The major clay minerals in weathering profiles developed over granitic gneisses (15/1) in Banasandra are kaolinite-smectite (HIS), smectite, clay micas and Fe-oxides (figure 5). Smectite is found in comparatively small amounts and is confined to the top and bottom parts of the profile (table 2). 060 reflections of strong $1.5 \AA$ and weak $1.54 \AA$ indicate that the dioctahedral mineral is more prominent than trioctahedral one (figure 5 inset). In the bottom-most sample (15/1 A), the $14.8 \AA$ peak expands to $16.32 \AA$ on glycolation and contracts to $10 \AA$ on $\mathrm{K}$ saturation indicating the presence of high-charge smectite. The $15 \AA$ peak is absent in the three samples collected above this and appears again in the top three samples. These smectites are identified as low charge smectites. Thus, high charge- and low charge-smectites are restricted to the bottom and top part of the profile respectively.

Low charge smectites make up $99 \%$ of the clay fraction in the weathered metabasalts (sample $14 / 2$ ) of this area. The only other clay mineral
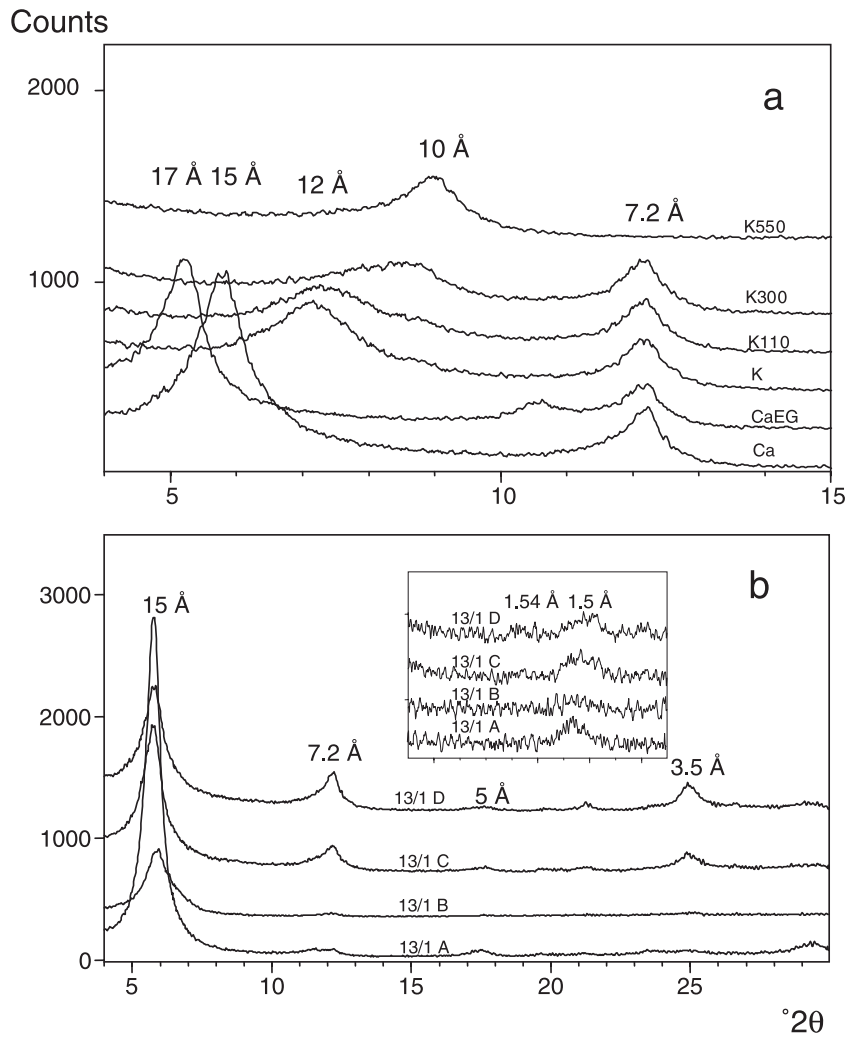

Figure 4. XRD patterns of clay fraction in samples from weathering profiles developed over ultramafic rocks (13/1) in Banasandra. Peaks are labeled with corresponding d-spacing in $\AA$ units. (a) XRD patterns of sample $13 / 1 \mathrm{D}$ after subjecting to various treatments and explanation for abbreviations is as given in figure 3 . The $15 \AA$ peak in the Ca-saturated sample expands to $17 \AA$ after glycolation confirming the presence of smectite. Upon K-saturation and heating to $110^{\circ} \mathrm{C}$, the $15 \AA$ peak collapses to $12-11 \AA$ indicating that these are low charge smectites. The $7.2 \AA$ peak shows a prominent low angle 'tailing' and on heating to $550^{\circ} \mathrm{C}$, the $7.2 \AA$ peak disappears and the $10 \AA$ peak becomes more intense compared to $110^{\circ} \mathrm{C}$ and $300^{\circ} \mathrm{C}$ heated peaks and shows a low angle tail. There is no shift of $7.2 \AA$ peak after glycolation. This peak represents kaolinite interstratified with a hydroxy interlayered smectite. (b) XRD patterns of four Ca-saturated samples from different zones of the same profile (13/1). Sample numbers are marked over the XRD patterns. The $7.2 \AA$ (kaolinite-smectite) peak becomes stronger towards the top of the profile. Inset shows the 060 reflections of $1.5 \AA$ for these four samples are more prominent compared to $1.54 \AA$ indicating dominance of dioctahedral component.

found in this profile is kaolinite-smectite interstratified mineral (table 2).

In the profile developed over greywacke, the major clay minerals present are smectite and interstratified kaolinite-smectite (HIS) (figure 6). The smectites are dioctahedral as evidenced by 060 reflections at $1.5 \AA$. Small amounts of clay mica and Fe-oxides along with trace amounts of vermiculite are also found. These vermiculites were identified by the reinforcement of $10 \AA$ peak on $\mathrm{K}$ saturation and subsequent heating although distinct $14 \AA$ peaks were absent. Interstratified 
Table 2. Clay mineralogy of weathering profiles developed around Banasandra located east of the Western Ghats.

\begin{tabular}{|c|c|c|c|c|c|c|}
\hline \multirow{2}{*}{$\begin{array}{l}\text { Parent } \\
\text { rock type }\end{array}$} & \multirow{2}{*}{$\begin{array}{l}\text { Sample } \\
\text { no }\end{array}$} & \multicolumn{5}{|c|}{ Clay mineral abundance in percentage } \\
\hline & & $\mathrm{sm}$ & kao-sm & $\mathrm{cm}$ & goe & ver \\
\hline \multirow{4}{*}{ Ultamafic } & $13-1 \mathrm{D}$ & 81.6 & 15.6 & - & 2.8 & $\operatorname{Tr}$ \\
\hline & $13-1 \mathrm{C}$ & 87.9 & 10.2 & - & 1.9 & $\operatorname{Tr}$ \\
\hline & 13-1 B & 97.9 & 2.1 & - & - & $\operatorname{Tr}$ \\
\hline & $13-1 \mathrm{~A}$ & 98.7 & 1.3 & - & - & - \\
\hline \multirow{2}{*}{ Metabasalts } & $14-2 \mathrm{D}$ & 99.9 & - & - & - & - \\
\hline & $14-2 \mathrm{C}$ & 99 & 1 & - & - & - \\
\hline \multirow{7}{*}{ Granitic gneisses } & $15-1 \mathrm{G}$ & 3.5 & 90 & 3 & 3.4 & - \\
\hline & $15-1 \mathrm{~F}$ & 26.1 & 69.5 & 2.9 & 1.6 & - \\
\hline & $15-1 \mathrm{E}$ & 0.4 & 94 & 4.1 & 1.5 & - \\
\hline & $15-1 \mathrm{D}$ & - & 15.8 & 2.7 & 1.4 & - \\
\hline & $15-1 \mathrm{C}$ & - & 96.8 & 1 & 2.3 & - \\
\hline & 15-1 B & 1.4 & 96.4 & 0.6 & 1.7 & - \\
\hline & 15-1 A & 6.31 & 92.6 & - & 1.1 & - \\
\hline \multirow{13}{*}{ Metagreywacke } & $16-2 \mathrm{M}$ & 91.1 & 4.6 & 4.3 & - & - \\
\hline & $16-2 \mathrm{~L}$ & - & 96.1 & 3.9 & - & - \\
\hline & $16-2 \mathrm{~K}$ & 61.5 & 36.4 & 2.1 & - & - \\
\hline & $16-2 \mathrm{~J}$ & 35.4 & 58.4 & 5.6 & 0.6 & - \\
\hline & 16-2 I & - & 96.2 & 3.8 & - & - \\
\hline & 16-2 H & 54.8 & 41.9 & 3.3 & - & - \\
\hline & $16-2 \mathrm{G}$ & 89.4 & 9.3 & 1.3 & - & $\operatorname{Tr}$ \\
\hline & $16-2 \mathrm{~F}$ & 89.9 & 8 & 2 & - & - \\
\hline & $16-2 \mathrm{E}$ & 92.9 & 5.9 & 1.1 & - & $\operatorname{Tr}$ \\
\hline & 16-2 D & 74.2 & 15.9 & 7.7 & 2.2 & $\operatorname{Tr}$ \\
\hline & $16-2 \mathrm{C}$ & 86.5 & 8 & 5.6 & - & $\operatorname{Tr}$ \\
\hline & $16-2 \mathrm{~B}$ & 84.9 & 12.3 & 2.8 & - & - \\
\hline & 16-2 A & 81.6 & 16.2 & 2.3 & - & - \\
\hline
\end{tabular}

$\mathbf{s m}=$ smectite $; \mathbf{k a o}-\mathbf{s m}=$ kaolinite-smectite interstratified mineral; $\mathbf{c m}=$ clay mica; goe $=$ goethite; ver $=$ vermiculite; $\mathbf{T r}=$ trace amounts .

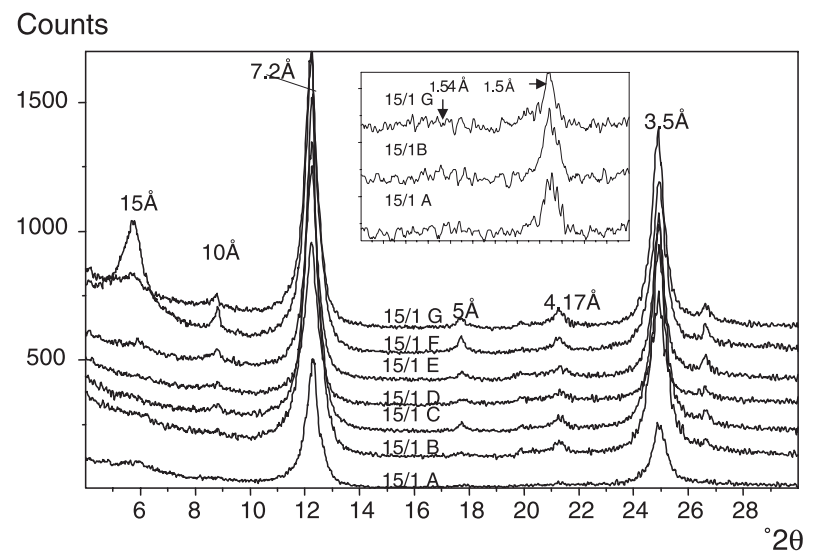

Figure 5. XRD pattern of samples from different zones of weathering profile over granitic parent rock in Banasandra. Sample numbers are marked over the XRD patterns. The peaks identified are: $7.2 \AA$ - kaolinite-smectite, $15 \AA$ - smectite, $4.17 \AA$ - goethite. In this sample also, the $1.5 \AA$ peak is more intense than the $1.54 \AA$ indicating that the 060 reflections are prominently from dioctahedral clays (inset).

kaolinite-smectite predominates in the upper part and smectite in the lower part of the profile. The variation in amounts of smectite and kaolinite-smectite interstratified mineral down the profile is shown in figure $7(\mathrm{~b})$.

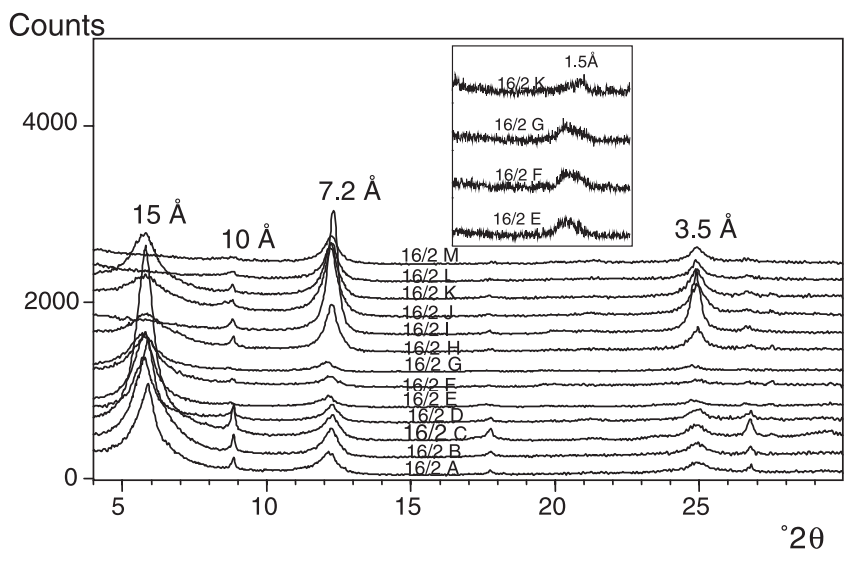

Figure 6. XRD patterns of samples from different zones of weathering profile over metagreywacke $(16 / 2)$. The peaks identified are: $7.2 \AA$ - kaolinite-smectite, $15 \AA$ - smectite, $10 \AA$ - clay mica, $4.17 \AA$ - goethite. Inset shows that the 060 reflections are more prominent at $1.5 \AA$ indicating dioctahedral character of clays.

In all the profiles from Banasandra, the intensity ratio of peak heights of 001 and 002 basal reflection of mica remain greater than one indicating the presence of both muscovite and biotite components in the clay fraction (Pal et al 2001). 
(a)
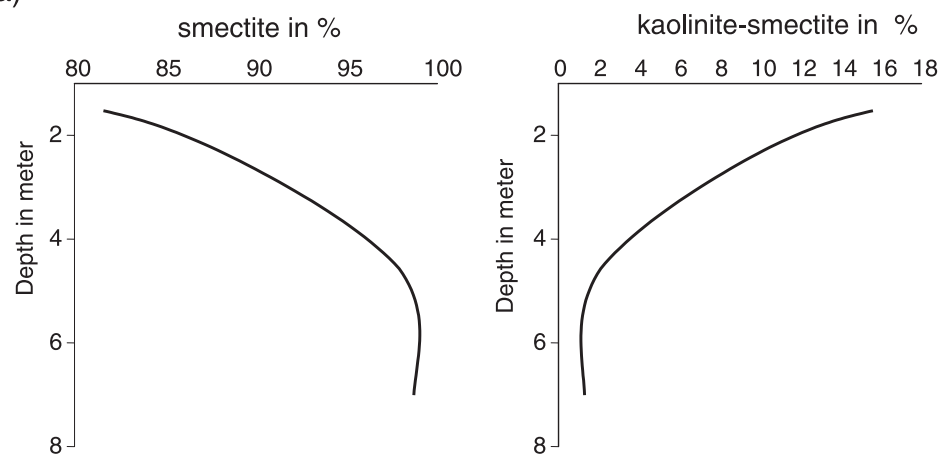

(b)

smectite in \%

kaolinite-smectite in \%
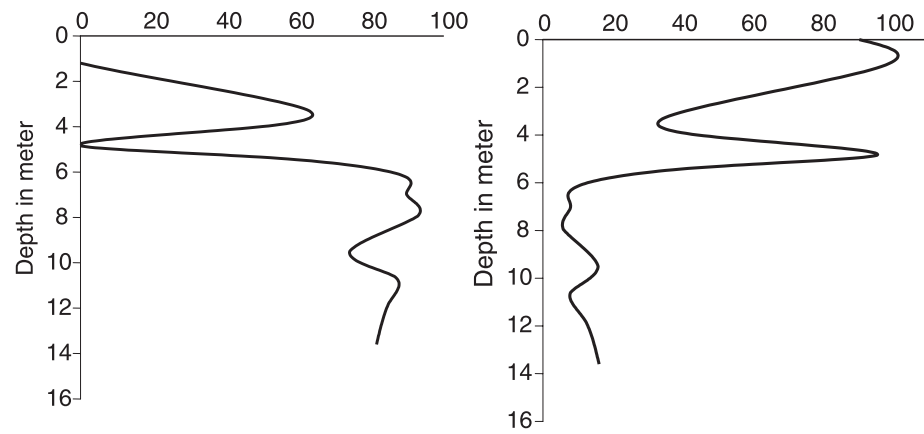

Figure 7. Variation in abundance of smectite and kaolinite-smectite with depth in profiles developed over (a) ultramafic rocks and (b) metagreywacke in Banasandra. (a) In the profile over ultramafic rocks, the amount of smectite increases and amount of smectite-kaolinite decreases with depth. As expected, the pattern of variation shows exactly opposite trends for the two minerals. (b) In the profile over metagreywacke, the amount of smectite is showing an increasing trend with depth although at about $5 \mathrm{~m}$ below surface, it decreases to zero. The highest amount of smectite is seen in the middle part of the profile at 7 to $8 \mathrm{~m}$ depth. Kaolinite-smectite interstratified mineral shows an opposite trend in this profile also.

Thus, in the rain shadow region the clay mineral assemblage in the weathering profiles developed over granitic gneisses are characterized by kaolinite-smectite, smectite, clay-mica and trace goethite. Whereas, profiles developed over comparable bedrocks in the high rainfall areas are characterized by gibbsite, kaolinite and goethite. Similarly, in the rain shadow region, weathering profiles developed over mafic/ultramafic rocks show a clay mineral assemblage of smectite, kaolinite-smectite and minor clay-mica and goethite and trace vermiculite, in contrast to, kaolinite, gibbsite and goethite assemblage found in high rainfall areas. Thus, the clay fractions of weathering profiles developed over similar parent rock types in the west coast and in the rain shadow region show distinctly different mineral assemblages.

\section{Discussion}

Uplift of Western Ghats (Sahyadri range) and onset of monsoonal climatic regime have resulted in heavy rainfall $(>2000 \mathrm{~mm})$ along the plains of west coast and much less rainfall (around $500 \mathrm{~mm}$ ) in the hinterland (Mysore plateau). However, the average annual temperatures of these areas are similar. This difference in rainfall is expected to influence the weathering pathways of rocks.

From the distribution of clay minerals in weathering profiles found on either side of the Western Ghats in Karnataka, it is observed that the pattern of weathering is different in these two regions. Formation of high amounts of kaolinite and $\mathrm{Fe}, \mathrm{Al}$ oxy-hydroxides in the weathered granitic gneisses of the western part shows higher intensity of chemical weathering. Weathering of mafic rocks also produces kaolinite, gibbsite and goethite in the high rainfall areas. Distinct 2:1 clay minerals are either absent or present only in trace amounts as vermiculite. Weathering profiles over granulites from the Mangalore area show some evidence for the presence of interstratified kaolinite-smectite. The smectite-kaolinite interstratification represents an intermediate phase of transformation of smectite to kaolinite. However, the extent of interstratification is very low as the transformation of smectite to kaolinite is almost complete. Such features are preserved only in weathering profiles over 


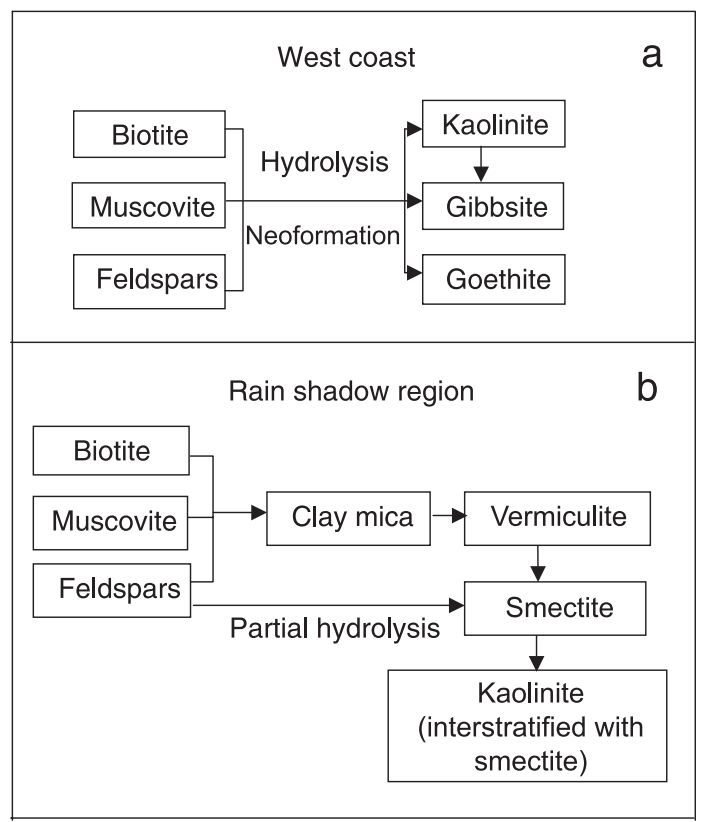

Figure 8. Representation of simplified mineral alteration patterns observed in the weathering profiles developed over rocks in the west and east of Western Ghats. (a) Due to the high amount of water available for weathering in the west coast, hydrolysis of primary silicate minerals leads to the formation of essentially 1:1 clay minerals and iron/aluminium oxyhydroxides. 2:1 minerals are less stable in this condition and transforms to 1:1 clays. (b) In the rain shadow region where total available water for weathering is much less, the immediate weathering products of primary silicate minerals are essentially 2:1 clays. The kaolinites observed in the eastern part are not pure kaolinites but are interstratified with hydroxy interlayered smectites (HIS). Thus these HIS interstratified kaolinites represent intermediate product of transformation of smectite to kaolinite. Such transformations must have taken place when the climate was more humid in the past. Thus the weathering reactions proceed through distinctly different pathways on either side of Western Ghats.

granulites and indicate relatively younger nature of these profiles compared to those on the granitic gneisses.

To the east of Western Ghats, formation of $\mathrm{Fe}-\mathrm{Al}$ oxy-hydroxides is very limited. Goethite is found only in trace amounts whereas gibbsite is totally absent in the samples analyzed from the eastern part. Formation of minor goethite could be as a result of weathering of Fe-oxide minerals such as ilmenite and magnetite, which are usually found as accessory phases in igneous and metamorphic rocks. Ilmenite and magnetite are relatively more abundant in amphibolites (metamorphosed komatiite or tholeiite) and hence their weathering will result in the formation of goethite as reported by Sharma and Rajamani (2000). Whereas, the goethite found in profiles west of the Western Ghats is essentially a residual mineral developed as one of the end products of intense chemical weathering.
The clay mineral assemblage of smectite, interstratified kaolinite-smectite and clay mica found in weathering profiles developed to the east of Western Ghats has important implications to the past climate. The present semi-arid climate cannot produce significant amounts of interstratified kaolinite-smectite. Occurrence of kaolinite-smectite represents transformation of smectites to kaolinite that takes place only under a humid climatic condition with abundant rainfall (Pal et al 1989) and requires a higher degree of leaching (Singer 1980). Also the warm semi-arid climatic conditions are not considered severe enough for transformation and weathering to kaolinite stage (Murali et al 1978). Therefore, the presence of interstratified kaolinite-smectite represents more humid and high leaching conditions that prevailed in the past.

The kaolinite is interstratified with smectites, which possibly contain hydroxy interlayer. According to Barnhisel and Bertsch (1989), in most acidic environments, hydroxy- $\mathrm{Al}$ interlayered smectites are intermediate minerals in the weathering sequence of micas as given below:

Mica $\rightarrow$ illite $\rightarrow$ vermiculite $\rightarrow$ smectite $\rightarrow$ hydroxy-Al interlayered smectite $\rightarrow$ kaolinite.

Trace amounts of vermiculites are present in the lower part of the profile over greywacke, which are considered to be a weathering product of mica in a semi-arid climatic condition. The profiles over granitic gneisses also show high-charge smectites (low charge vermiculites) in the lower parts, which again, are considered to be a weathering product of mica in a semi-arid climatic condition. Thus the presence of trace vermiculites and high-charge smectites in the lower parts of the profiles, that represents recent weathering, indicate more arid conditions.

Based on the clay mineral assemblage developed in areas occurring east of the Western Ghats, it is inferred that the climate has changed from relatively more humid in the past to present day semiarid regime. Pal et al (1989) have suggested that climate changed from tropical humid to semi-arid during the Plio-Pleistocene transition period coinciding with the rise of Western Ghats.

\subsection{Uplift and chemical weathering}

The Sahyadri range (Western Ghats), adjoining west coast and Mysore plateau are considered to be tectonically active from Mesozoic till recent (Radhakrishna 1968, 1993; Valdiya 1989, 1998; Gunnel 1998). Tectonic uplift is usually followed by increased denudation and transport. Several studies have indicated that there is no clear relationship between chemical weathering and uplift 
(e.g., Drever and Zobrist 1992; White and Blum 1995). Clay mineral genesis is related to chemical weathering and hence the clay mineralogy of weathering profiles will not directly depend on uplift.

For weathering one meter of fresh rock, it will take several thousands of years (Nahon 1991) and therefore, the clay mineralogy reflects time integrated effect of climate on chemical weathering reactions. White and Blum (1995) have found that temperature and precipitation are the most important factors that control the rate of chemical weathering on the basis of their study of different watersheds. We suggest that distinct difference in the rainfall is the most significant factor in the development of contrasting clay mineral assemblages on either side of Western Ghats. Higher rainfall and leaching leads to transformation of primary minerals like feldspar, biotite and muscovite directly to kaolinite, gibbsite and goethite. Whereas, low rainfall leads to insufficient leaching of silica and other cations resulting in the formation of 2:1 clay minerals like smectites and vermiculites (figure 8). Thus distinct chemical weathering reactions take place in high- and lowrainfall regions.

\section{Conclusions}

- The weathering of rocks to the west and east of Western Ghats leads to the development of distinctly different clay mineral suites in the weathering profiles.

- The extent of chemical weathering is more in the western part as evidenced by clay mineral assemblages dominant in iron aluminium oxyhydroxides and kaolinite irrespective of the parent rock type.

- Weathering profiles in the eastern part have more complex clay mineralogy and indicate less intense chemical weathering.

- Rainfall is the most significant factor influencing chemical weathering and clay mineral genesis in the study areas, which are in the tropical region.

- Weathering reactions of minerals proceed through different pathways in water rich and water poor environments.

- Occurrence of significant amounts of interstratified kaolinite-smectite in weathering profiles from Banasandra area (east of Western Ghats) indicates a more humid paleoclimate prior to the uplift of the Western Ghats.

\section{Acknowledgements}

The authors thank Prof. R Vaidyanathan for introducing them to the topic of climate and weathering. Prof. V Rajamani, Jawaharlal Nehru University, New Delhi and Dr. K Pandarinath, Mangalore University are thanked for helping in XRD analysis during the initial phase. Help rendered by Dr. D K Pal, National Bureau of Soil Survey and Land Use Planning, Nagpur in $\mathrm{XRD}$ analysis and mineral characterization is gratefully acknowledged. The authors are thankful to the reviewers for their constructive comments. R Deepthy acknowledges financial support from UGC in the form of a Junior Research Fellowship.

\section{References}

Amiotte-Suchet P and Probst J L 1993 Modeling of atmospheric $\mathrm{CO}_{2}$ consumption by chemical weathering of rocks: application to the Garonne, Congo and Amazon basins; Chem. Geol. 107 205-210.

Barnhisel R I and Bertsch P M 1989 Chlorites and hydroxyinterlayered vermiculite and smectite. In: Minerals in soil environments; (eds) Dixon J B and Weed S B, Soil Science Society of America Madison (Wisconsin USA) Pp. 729-779.

Bourgeon G 2001 A Survey of Soils and Weathering Patterns through Land System mapping in the Western Ghats Region. In: Sahyadri, The Great Escarpment of the Indian Subcontinent; (eds) Gunnel Y and Radhakrishna B P, Geological Society of India, Bangalore, Pp. 855-904.

Brown G and Brindley G W 1980 X-ray diffraction procedures for clay mineral identification. In: Crystal Structures of Clay Minerals and their X-ray Identification; (eds) Brindley G W and Brown G, Mineralogical Society London, Pp. 305-360.

Dikshit K R 1979 Anomalies in the distribution of rainfall on the west coast of India; Indian Geogr. J. 54 1-13.

Drever J E and Zobrist J 1992 Chemical weathering of silicate rocks as a function of elevation in the southern Swiss Alps; Geochim. Cosmochim. Acta 56 3209-3216.

Galehouse J S 1971 Sedimentation analysis. In: Procedures in sedimentary petrology; (eds) Carver R E (New York: Wiley-Interscience) Pp. 65-94.

Gipson M 1963 Ultrasonic disaggregation of clays; J. Sedim. Petrol. 33 955-958.

Gunnell Y 1998 Present, past and potential denudation rates: is there a link? Tentative evidence from fissiontrack data, river sediment loads and terrain analysis in the South Indian shield; Geomorph. 25 135-153.

Gunnell Y and Louchet A 2000 The influence of rock hardness and divergent weathering on the interpretation of apatite fission track denudation rates. Evidence from charnockites in South India and Sri Lanka; Geomorph. $4433-57$.

Hardy R G and Tucker M E 1988 X-Ray Powder Diffraction of Sediments. In: Techniques in Sedimentology; (eds) Tucker M E (London: Blackwell Scientific Publications) Pp. 191-228.

Huh Youngsook 2003 Chemical weathering and climate - a global experiment: a review; Geos. J. 7 227-288.

Millot R, Gaillardet J, Dupre B and Allegre C J 2003 Northern latitude chemical weathering rates: clues from the Mackenzie River Basin, Canada; Geochim. Cosmochim. Acta 67 1305-1329.

Mortatti J and Probst J L 2003 Silicate rock weathering and atmospheric/soil $\mathrm{CO}_{2}$ uptake in the Amazon basin 
estimated from river water geochemistry: seasonal and spatial variations; Chem. Geol. 197 177-196.

Murali V, Murthy G S R K and Sarma V A K 1978 Clay mineral distribution in two toposequences of tropical soils of India; Geoderma 20 257-269.

Nahon D B 1991 Introduction to the petrology of soils and chemical weathering; (New York: John Wiley \& Sons Inc) p. 313.

Omotoso O E and Mikula R J 2004 High surface areas caused by smectitic interstratification of kaolinite and illite in Athabasca oil sands; Appl. Clay Sci. 25 37-47.

Pal D K, Deshpande S B, Venugopal K R and Kalbande A R 1989 Formation of di- and trioctahedral smectite as evidence for paleoclimatic changes in southern and central peninsular India; Geoderma 45 175-184.

Pal D K, Srivastava P and Durge S L 2001 Role of weathering of fine-grained micas in potassium management of Indian soils; Appl. Clay Sci. 20 39-52.

Pandarinath K, Prasad Sushma, Deshpande R D and Gupta S K 1999 Late Quaternary sediments from Nal Sarovar, Gujarat, India: Distribution and provenance; Proc. Indian Acad. Sci. (Earth Planet. Sci.) 108 107-116.

Probst J L, Mortatti J and Tardy Y 1994 Carbon river fluxes and global weathering $\mathrm{CO}_{2}$ consumption in the Congo and Amazon river basins; Appl. Geochem. 9 1-13.

Radhakrishna B P 1968 Geomorphological approach to the charnockite problem; J. Geol. Soc. India 9 67-74.
Radhakrishna B P 1993 Neogene uplift and geomorphic rejuvenation of the Indian Peninsula; Curr. Sci. 64 (11\&12) 787-793.

Schultz L G, Shepard A O, Blackmon P D and Starkey H C 1971 Mixed layer kaolinite-montmorillonite from the Yucatan Peninsula, Mexico; Clays Clay Miner. 19 $137-150$.

Sharma A and Rajamani V 2000 Major element, REE, and other trace element behavior in amphibolite weathering under semi-arid conditions in southern India; J. Geol. 108 487-496.

Singer A 1980 The paleoclimatic interpretation of clay minerals in soils and weathering profiles; Earth-Sci. Rev. 15 303-326.

Srivastava P, Parkash B and Pal D K 1998 Clay minerals in soils as evidence of Holocene climatic change, Central Indo-Gangetic plains, North-central India. Quat. Res. 50 230-239.

Valdiya K S 1989 Neotectonic implication of collision of Indian and Asian plates; Indian J. Geol. 61 1-13.

Valdiya K S 1998 Late Quaternary movements and landscape rejuvenation in southern Karnataka and adjoining Tamil Nadu in southern Indian Shield; J. Geol. Soc. India 51 139-166.

Velde B 1992 Introduction to Clay Minerals; (London: Chapman \& Hall) p. 198.

White A F and Blum A E 1995 Effects of climate on chemical weathering in watersheds; Geochim. Cosmochim. Acta 59 1729- 1747. 